\title{
Bracketing: A Phenomenological Theory Applied Through Transpersonal Reflexivity
}

\begin{abstract}
Purpose

The purpose of this study is to improve our understanding of bracketing, one of the most central philosophical and theoretical constructs of phenomenology, as a theory of mind. Furthermore, we wanted to showcase how this theoretical construct can be implemented as a methodological tool.

Design/methodology/approach
\end{abstract}

In this study we have adopted an approach similar to a qualitative meta-synthesis, comparing the emergent patterns of two empirical projects, seeking synergies and contradictions, and looking for additional insights from new emerging patterns.

\section{Findings}

On a philosophical level, we have found that bracketing, as a theoretical construct, is not about the achievement of objectivity, quite to the contrary, it embraces subjectivity and puts it centre-stage. On a theoretical level, we have achieved a better understanding of Husserl's phenomenology, as a theory of mind. On a methodological level, we have achieved a powerful way of supplementing and/or clarifying research findings, by using a theoretical construct as a methodological tool.

\section{Originality/value}

Our paper contributes to the phenomenology literature at a philosophical, theoretical and methodological level, by offering a better understanding and a novel implementation of one of the central theoretical constructs of phenomenology.

Keywords: bracketing, phenomenology, reflexivity, reflection

Article classification: research paper 


\section{INTRODUCTION}

In this article, we make a new case for an old and often forgotten method: bracketing. As a first approximation, which we will refine throughout the article, bracketing can be conceptualised as the researchers' attempt to hold in abeyance their pre-understandings and assumptions to attain experiences before making sense of them. While bracketing is primarily a philosophical and theoretical concept, as phenomenology is a philosophy and a theory of the mind, a phenomenological method is incomplete unless it accounts for bracketing. Therefore, in this article, we explore the process of bracketing, provide an argument for its significance, and offer a reasonably straightforward way of implementing it through what we call transpersonal reflexivity. By doing so, in addition to helping interested readers build a phenomenological method for themselves, we also support reflexivity, which is one of the distinguishing features of good qualitative research.

In order to achieve this, we showcase how phenomenology as a theory of mind has informed and guided two studies in which we applied the method of bracketing. Both studies were aimed at studying high-complexity phenomena related to extraordinary achievers. In the first one, we were focusing on the cognitive complexity of top scientists (20 in total, 17 of them Nobel Laureates). In the second one, we were focusing on the creativity of top chefs (19 in total, 18 Michelin-starred). In both of these studies we have adopted a variant of phenomenological inquiry, utilised in-depth interviews, and developed specific phenomenological methods in both cases, in order to cope with the complexity of the phenomena we were researching. In both studies, we implemented bracketing through transpersonal reflexivity by engaging in reflexive conversations between researchers, and we argue that bracketing served as a source of additional insights supplementing and/or clarifying the research findings. Thus, there is sufficient phenomenological similarity between the two studies to bring them together in a reflexive exploration of how we engaged in and used bracketing.

Bracketing is a core concept in phenomenological theory but is also highly controversial. The main reason for this is that phenomenology has provided theoretical grounding for interpretivists as well as positivists, and bracketing means very different things depending on which philosophical underpinnings are adopted. In this article, we address bracketing in an interpretivist framework, and bring it together with the concepts of reflection and reflexivity, which are central to interpretivist research today, and widely regarded as crucial in any rigorous qualitative study. Thus, we address a gap between the somewhat esoteric notion of bracketing in the phenomenology literature and the phenomenological research taking place in the real world. While bracketing as a theoretical construct is sound, its implementation as a research tool, is often inadequately addressed or skipped entirely. We believe that one of the reasons is that there is shortage of implementation guidelines. We offer such guidelines, but not in the form of an instant tool that can be added without thinking - as we will explain, each instance of implementing bracketing through transpersonal reflexivity will be unique and (trans)personalised. 
As we were trying to make the most out of our immensely rich empirical material in both above-mentioned projects, we have realised that we engaged in the practice of bracketing. Using an approach similar to meta-synthesis, we started to take stock of anecdotal evidence in the form of retelling the stories that we have experienced during the two studies. Previously we had realised that we could identify numerous similarities between the top scientists and the top chefs, this time we were interested in the similarities of the two research processes - beyond the fact that they felt very similar, even though technical details were different. One of the dominant similarities was about bracketing - we have engaged in bracketing in both studies, in only slightly different ways, although it was not our intention at the time to develop a formalised approach to bracketing. However, we realised that there are two robust aspects of bracketing that were common between the two studies and, in combination, they seem to be unique in the methodological realm: in both cases we have gone through bracketing as a transpersonal process, and in both cases this process involved reflection and reflexivity. Therefore we decided to explore this notion more systematically.

In order to unpack the concept of bracketing as seen in the two underlying empirical studies, we structure this paper as follows. First we briefly revisit and outline the central concepts of phenomenological theory. Then we provide a short summary of the two empirical studies that underlie the subsequent theorising; particularly focusing on their methodological processes. Next we make some preliminary notes on bracketing, as it has been implemented in the two empirical studies. Finally, we revisit the phenomenological concept of bracketing in more detail, discuss how we have applied it in the underlying studies and introduce the attribute of 'transpersonal,' applying it to the notion of reflexivity, in order to understand this specific way of implementing bracketing in interpretivist-qualitative studies. In our concluding remarks we emphasise the significance of the improved understanding of bracketing and its usefulness as a methodological tool, also exploring its implications.

\section{PHILOSOPHICAL BACKGROUND OF PHENOMENOLOGICAL THEORY}

Phenomenology was founded by Edmund Husserl, at a time when the world of science and philosophy was profoundly positivist. Even Husserl's teacher, Franz Brentano (1973 $)^{[1]}$, remained within the positivist paradigm and tried to establish exact laws of the functioning of the human mind. Husserl attempted to establish new foundations of doing research and thereby faced strong opposition, because those foundations departed from the positivist ideal of scientific inquiry by focusing on the notion of lived experience. Lived experiences cannot be separated from the context of the experience and from the pre-understandings of the researchers as well as of the research participants, notions that are unacceptable in the traditional positivist approach to scientific research.

${ }^{[1]}$ Brentano's book was originally published in 1874 in German: Psychologie vom empirischen Standpunkte. The basis of the translation used here is the second edition published in 1924 . 
To date, phenomenological theory is still sometimes used on positivist ontological and epistemological basis, although this cannot be considered dominant anymore. Due to the nature of the lived experience, today most phenomenological inquiries are positioned within a variant of interpretivism, although the degree of subjectivity adopted by different authors varies greatly.

The most elusive aspect of the lived experience is captured in the central concept of phenomenology, as a theory of mind, called qualia, which is a term that refers to the part of the lived experience that cannot be put into words. Qualia ${ }^{[2]}$ are the part of our experience that appears in our consciousness, accessible only via introspection, describable only in subjective terms (Eliasmith and Mandik, 2006), and even a conscious introspection only leads to a 'feel': a metaphor and tacitly recognised patterns (Varela and Shear, 1999a, 1999b; Sadler-Smith, 2008). For instance, you cannot fully explain to someone what it feels like having butterflies in your tummy when kissing your lover or the joy you felt as a child when you smelled your grandmother's strawberry cake and realised that summer is around the corner. The term qualia, introduced by Lewis (1929), is probably easiest to understand through Jackson's (1982) renowned thought experiment about Mary and the rose. Here is a personal recap of the story. Mary had grown up in a completely black-and-white environment; she was never allowed to leave her room or to see nature. She had never seen any colour apart from black and white. At the same time, she had been educated about the physics of colours, about perceiving them, about the biology of seeing and anything that can be explicitly taught about colours. She had learned everything that can be learned about the colours from others, without actually experiencing anything in colour herself. Then, for the first time in her life, she leaves her room. She sees a red rose and passes out. Although the story remains in some ways unfinished, i.e. we do not find out what finally happened to Mary, the message is clear: there is something in the lived experience that cannot be fully explained verbally, something that needs to be experienced personally. (See also Chalmers, 2003) Phenomenologists usually argue that qualia are the essences of the lived experience, not to be confused with the theorised essences we aim to carve out from the phenomena we study. In management and business research the role of the lived experience of human beings in the work place is likely to be significant to the behaviour of people we study in organizations.

Then, there are two further fundamental concepts in phenomenological theory; these account for the impossibility of divorcing the lived experience from its context of the person's existence. In phenomenological terms, the latter is called Dasein (usually translated into English as 'existence' or 'being there'), which we describe as the idea that being human/scientist/chef carries a 'meaningfulness of self-realization', while the wider context, including the personal history, social aspects, and the pre-understandings of the experiencer, is referred to as Lebenswelt (usually translated into English as 'life-world'). We adopt the original German terms here instead of the translations, as this is customary in the field of

[2] Qualia is plural, the singular would be 'quale'. The default use in phenomenology is the plural form. 
phenomenology and the English translations do not convey the full meaning of the original notions.

Historically the notion of Lebenswelt appeared first, as the notable attempt of phenomenological theory to combat the positivist notion of isolability of phenomena, which has been considered inadequate. Husserl (1913a, 1913b, 2006) assigned central importance to the theme of Lebenswelt, the spatio-temporal context in which the lived experience happens. Intentionality is also a component of the Lebenswelt, which connects phenomenological theory with the theory of mind inherited from Brentano. In turn, MerleauPonty (1945, p vii) argues that phenomenology is a study of essences but also "a philosophy which puts essences back into existence", so into their Lebenswelt. This argument provides an excellent description of the phenomenological quest. For Gadamer (1989, p 239), Lebenswelt is "the antithesis of all objectivism"; it is the whole in which humans live as historical creatures and, at the same time, a communal world of being together.

Introducing the concept of Dasein, Heidegger describes the primary sense of being in the Lebenswelt. Furthermore, Dasein which "itself is out for and going toward something" (Heidegger, 1923, p 51) also helps Heidegger getting away from the object-subject dichotomy by bringing intentionality into the Dasein (Heidegger, 1975, p 64). Furthermore, this conceptualisation of Dasein emphasises its ephemeral nature, thus connecting it more tightly with the notion of qualia: both qualia and Dasein only exist as one-off descriptors of experiencing. In the case of the next experiencing, both the qualia and the Dasein will be different. In contrast, while Lebenswelt also changes over time, this process of change is usually slower for the Lebenswelt is more robust.

One of the potential strengths of a phenomenological inquiry, if conducted properly, stems from the three fundamental concepts of phenomenology described so far: qualia embedded in the Dasein and in the broader Lebenswelt. These three concepts with their relationships can help researchers to escape the trap of representationalism, as the idea is to work with the lived experiences in the contexts in which they occur. Based on Woolgar (1988), Chia (1995, pp. 586-590) explains that more often than not, representationalism leads to an epistemological triple-fallacy (cf the 'Fallacy of Misplaced Correctness' in Whitehead, 1926): reification, inversion and forgetting. First, by speculation, we arrive at a representation of something that we cannot know whether it exists or not and we project the existence of an object that corresponds to this representation. Reification is the process in which "the speculated object begins to take on a life of its own" (Chia, ibid: 589). Then, we invert the roles between the reified object and the representation from which it originates, presenting what appears to be a legitimate reason for our research, i.e. that we have found an existing object in the first place. Finally, we forget about how the imagined object came into existence, and it is assumed to have become part of reality.

We do not intend to explore the dynamics between the Dasein and the Lebenswelt in this study; these notions are only important to us as a way of framing our understanding of bracketing. The way in which phenomenological theory addresses the problem of 
representationalism is through the fourth fundamental concept of phenomenology: bracketing. However, before we get into a detailed discussion of bracketing, we introduce the underlying empirical studies, particularly their methodological stances.

\section{THE UNDERLYING EMPIRICAL STUDIES}

The basis of the theorising presented here is two underlying empirical projects. In the first one, the first-named author interviewed 20 top scientists, including 17 Nobel Laureates, trying to understand cognitive complexity at the highest level of knowledge. (Dörfler and Eden, 2017; Feuls, Stierand, Dörfler, Boje, and Haley, 2019) In the second one, the secondnamed author interviewed 19 top chefs, 18 of them having been recognised with Michelin stars, in order to understand their creativity. (Stierand and Dörfler, 2012; Stierand, Dörfler, and MacBryde, 2014; Stierand, 2015; Stierand and Dörfler, 2016) Hence, both studies aimed at a high-complexity phenomenon in a well-defined context (science and haute cuisine respectively) and aimed at understanding the experiences of extraordinary achievers in these contexts. (Maslow, 1968, 1970; Gardner, 1993, 1995; Csíkszentmihályi, 1997; Gardner, 1997; Nakamura, Shernoff, and Hooker, 2009; Dörfler and Stierand, 2019) Both studies have been grounded in an interpretivist stance, and in both cases we were trying to collect thick data and achieve deep and insightful learning; this led us to develop a new method for each of the studies. The method developed for the Extraordinary Scientists project is called Intuitive Cyclic Phenomenology (Dörfler and Eden, 2014), emphasising that it explicitly incorporates the intuition of the researchers and it has a number of embedded cycles in the process. The method developed for the Extraordinary Chefs project is called Insider Explanatory Phenomenology (Stierand and Dörfler, 2014), as it explicitly incorporates the insider view of the researcher, who previously worked as a chef in Michelin-starred restaurants and the purpose was to develop an interpretive-explanatory model. Here, we bring these two projects together, adopting an approach similar to a qualitative meta-synthesis, comparing the emergent patterns of both projects, seeking synergies and contradictions, and looking for additional insights from new emerging patterns. (Bondas and Hall, 2007; Park and Gretzel, 2007; Sandelowski and Barroso, 2007)

\section{Intuitive Cyclic Phenomenology}

In order to obtain the richest data we used loosely structured open-ended in-depth interviews (e.g. as in Fontana and Frey, 1994) from the outset, although the earlier interviews inevitably informed the later ones. However, we deliberately tried to keep the interviews as open as possible, simply to have meaningful conversations with the interviewees on any topic with respect to their approach to research, to let salient characteristics naturally emerge. One of the authors conducted all the interviews and learned in advance as much as possible about both the research and personal histories of the interviewees and so this pre-reading became a source of data and pre-understanding. 
To preserve most of the richness of the interview experience, the co-researcher of the Extraordinary Scientists project conducted a series of interviews and concept mapping sessions ${ }^{[3]}$ with the interviewer, trying to capture the changes in his intuitive understanding of cognitive complexity. The concepts that emerged from these sessions were then used as the basis for a more formal coding of the interviews with the Extraordinary Scientists using a variant of content analysis in NVivo ${ }^{[4]}$. During the coding process additional codes emerged, which were discussed in subsequent meetings between the two researchers and added to the concept maps. There were numerous iterative cycles employed resulting in a stable structure of findings. Some of the findings were unexpected and emergent, such as the characteristics of successful research as seen by the interviewed Extraordinary Scientists.

It is perhaps apparent that in the process of 'interviewing the interviewer' and concept mapping sessions the preunderstandings of the interviewer and particularly his intuition have been discussed - i.e. the researchers engaged in bracketing.

\section{Insider Explanatory Phenomenology}

Insider Explanatory Phenomenology starts with open-ended loosely structured interviews, very similar in approach to the above-described interviews. In addition, it explicitly builds on the interviewer's (here second-named author) professional history, having been a chef in Michelin-starred restaurants before embarking on an academic career. This is emphasised by the 'insider' notion in the name of the method. We have been repeatedly criticised for the 'lack of objectivity' of our approach, because of the interviewer's chef history. At the same time, we have seen this as a major advantage, as a source of insight, as "inherited background" (Wittgenstein, 1979, p §94). Over time, we were able to convince our peers by the quality and richness of the data an insider is capable of collecting and analysing and, now, with a more elaborate understanding of the notion of bracketing, we can also provide a rigorous and dependable method.

In terms of analysis, this contextualist research approach consists of two phases, the first we call idiographic description, the second idiographic explanation. The first phase builds on Giorgi's (1985b, 1994) descriptive phenomenology as we find it particularly suitable for research questions that aim to identify the essential structures underlying the experiences of a phenomenon, and thus prefer it over other phenomenological approaches that, for instance, aim to capture individual variations between co-researchers (Finlay, 2008b). In addition, we applied a second interpretive-explanatory level of analysis, building on the interviewer's past experience as a chef. The purpose of the second level was to explain what we have learned about the lived experiences of personal creativity from the interviewees' accounts and their self-observations. In this sense, the second level of analysis is a 'metalevel' of the findings from the first level, that may be seen as a pattern existing beyond the descriptive findings, or as particular implications of the descriptive findings, their essence,

\footnotetext{
[3] Using a causal mapping software strategyfinder (www.strategyfinder.pro).

${ }^{[4]}$ NVivo is software designed to facilitate content analysis (www.qsrinternational.com/).
} 
their structure, or loosely coupled associations. The second level of analysis was predominantly intuitive, during which, instead of rejecting the subjective experience and expertise in the domain, the interviewer had to get immersed in it so completely, that it was possible to grasp the essential nature of the phenomenon. Obtained this way, the concept of the personal creativity of chefs was brought to the surface, however, it was embedded in the Lebenswelt of chefs and in the Dasein of the particular culinary hot spot. Therefore the interviewer had a discussion with his co-researcher (here the first-named author), who does not have an haute cuisine background, but has his Dasein in the Lebenswelt of creativity scholars. In this conversation, as in a translation process (cf. Cassell and Lee, 2017), the findings were re-contextualised, thus becoming accessible to a wider audience of creativity researchers. The interaction between the two researchers was a form of bracketing.

\section{'Bracketing' in the Two Studies}

Naturally, in both empirical projects outlined above, the bracketing construct of phenomenological theory came up as an important consideration, and we have developed a way of implementing it as a methodological tool through transpersonal reflexivity; only we did not know at the time that this is how we will call it. This study aims to unpack this view of bracketing, as we believe that doing it well can substantially increase the quality of the findings and it has relevance to many other inquiries conducted following similar research philosophical, meta-theoretical or theoretical considerations. Important to mention is that we do not see the use of intuition and the insider view as limitations, to the contrary, we believe that these were indispensable aspects of the research process and key for achieving significant and game-changing findings. Thus, the notion of bracketing, as we describe it here and as we have applied it, is not about getting rid of subjective components and removing pre-understandings but raising awareness of them, so that they can be explored, made use of, and explicitly incorporated.

A particularly powerful example of bracketing for the Extraordinary Scientists study was a direct source of additional insight. The interviewer made a remark about the masterapprentice relationship, to which the co-researcher replied along the lines of: "You already expected that everyone needs to go through a master-apprentice relationship in order to achieve the highest level of expertise, you mentioned it before you even started the interviews." The interviewer replied: "No, I said that anyone, with the possible exception of the genius, has to go through a master-apprentice relationship." What was the additional insight? That even the genius ${ }^{5}$ needs to go through a master-apprentice relationship. If the bracketing did not take place, if the underlying pre-understandings were not explicitly spelled out, it would have been simply a note that everyone seems to need to get through a master-

[5] We do not intend to elaborate the concept of genius here; Nobel Laureates are not necessarily geniuses. However, one of the interviewees in the Extraordinary Scientists study qualifies as a genius (possibly others too, but this was not investigated), and later on the interviewer also checked historical examples, such as the one of Mozart described by Gardner (1997). 
apprentice relationship. The emphasis on 'even the genius' increases and solidifies the insight's scope of validity.

The interviewer in the Extraordinary Chefs study experienced a powerful emotional insight, through bracketing, linking to an old memory. Over a decade before the study, the interviewer was a chef apprentice. His boss, a famous Michelin-starred chef in Germany, once told him: "First you have to master the craft and when I wake you up at 3 o'clock at night you must be able to tell me without thinking how to make a Sauce Hollandaise and only then you can start becoming creative!" The interviewer intellectually understood this then and there. However, during the bracketing process he connected to this memory emotionally, leading to a deeper insight. As the interviewer was telling a dialogue from an interview, his co-author asked him about a chef's focal awareness when cooking, about how, as a chef, he could 'forget' about the knife and be immersed in his creative sensibility. In an instant, the interviewer was back in his chef-apprentice time, not only intellectually but also emotionally understanding what the Michelin-starred master said. This new comprehension bracketed out the intellectual pre-understanding and the two authors recognised that extraordinary creative chefs are not so much representative of the population of chefs but much more representative of the phenomenon of creativity - this was a seed that grew into a book chapter published nearly a decade later. (see Dörfler and Stierand, 2019)

As we were primarily interested in the personal experiences of our interviewees, we needed to deal with the fact that these personal experiences cannot be separated from the context of the experience. Therefore, we considered the interviewees' Dasein, as well as their broader spatio-temporal context, the Lebenswelt, that also accounts for the intellectual tradition and domain knowledge of the interviewees' field of practice. In a sense, the Extraordinary Scientists projects also made use of the insider view, as the interviewer, as a researcher, is naturally part of the Lebenswelt of scientists at large. Yet, having not been awarded a Nobel Prize himself, he needed to prepare for each interview meticulously in order to establish communication and rapidly win the trust of the interviewees in the first few minutes of the interview. This is only a little glimpse into two extremely enriching and fascinating research experiences that both continuously challenged our personal worldviews and required from us to revise some of the fundamental theoretical constructs of phenomenology, particularly the issue of bracketing.

\section{BRACKETING REVISITED}

For a long time, scholars understood Husserl's notion of bracketing as an attempt to approximate the positivist ideal of objectivity, because they believed that any form of scientific inquiry needs to remove the researcher from the findings. We believe that this was not Husserl's intention. He talks about the "naïveté of objectivism" that needs to be overcome, as attempted by the German idealists, starting with Kant (Husserl, 1965, p 181). Importantly, we have achieved this understanding, only once the second-named author read Husserl's original work in German. In order to substantiate our belief, we first briefly review 
Husserl's approach to bracketing. We also want to highlight that making our belief explicit and unpacking it is also an instance of bracketing, which is in this case applied onto itself, perhaps it could be labelled meta-bracketing.

Husserl (1913a) talked about three forms of bracketing, three related theoretical constructs: the epoché or phenomenological attitude; the phenomenological psychological reduction; and the transcendental phenomenological reduction.

Epoche describes the mode in which the researcher refrains from explanations, scientific conceptions and knowledge so as to "return to the unreflective apprehension of the lived, everyday world". (Finlay, 2008b, p 3) This is a critical position where nothing is taken for granted (Merleau-Ponty, 1945; Zaner, 1975), beliefs, values, or knowledge about the phenomenon are "put out of play" (Husserl, 1936, p 237); the researcher refrains from judgment (Husserl, 1913a, 1936; Moran, 2000). In a sense, this first theoretical construct comprises the sensations (including feelings, emotions, impressions, etc.), as the first level of the lived experience in context. In other words, it is all about sensing while sensemaking is suspended. (cf Dörfler and Bas, 2020a)

Phenomenological psychological reduction, in turn, only requires the researchers (Giorgi, 1997) to suspend their "belief in the existence of what presents itself in the life-world. Instead the focus is on the subjective appearances and meanings" (Finlay, 2008b, p 3). So, the researcher brackets the world but not the empirical subject, to experience the natural attitude of the person in all its mundanity (Husserl, 1936; Giorgi, 1997). In other words, the second theoretical construct allows the research participant, but not the researcher, to make sense of the sensations.

Finally, transcendental phenomenological reduction is "a more radical version of the epoché where a 'God's eye view' is attempted" (Finlay, 2008b, p 3); Husserl argued that it allows the philosopher to be "above his own natural being and above the natural world" (Husserl, 1936, $\mathrm{p}$ 152). To put it differently, this third theoretical construct, proposes an opposite direction from the previous two, the research participant is abandoned, while the researcher attempts to understand the essence of the phenomenon under scrutiny. This third form of bracketing can be better understood using Polányi's notion of indwelling (Polányi, 1962b, 1962a; see also Dörfler and Stierand, 2018), according to which the greatest scientific breakthroughs are achieved by the scientists' complete indwelling in the phenomenon, summoning all their knowledge of the subject and their understanding of science in general. Polányi (1969) uses Einstein's example of perceiving the theory of relativity, arguing that through complete indwelling Einstein intuitively (cf Dörfler and Ackermann, 2012) made the assumption that a light source would never overtake a beam sent out by it, although he was not familiar with the outcome of the Michaelson-Morley experiment.

Some later interpretations of the theoretical triple-construct of bracketing shifted towards what we wanted to achieve. For instance Gadamer (1989, p 237), advancing his interpretivist agenda, finds the essence of phenomenology in "bracketing all positing of being and 
investigating the subjective modes of given". Giorgi (1994, p 212) considers it as a process whereby "one looks at the data with the attitude of relative openness". Finlay (2009, p 13) talks about a "dialectic movement between bracketing preunderstandings and exploiting them reflexively as a source of insight". Similarly, the approach in these cases is aligned with our intentions to understand the interviewees' perspective including the identification of elements that blur the invariant but essential nature of the interviewees' experiences (Husserl, 1931; Giorgi, 1994). This is also the reason for the numerous iterative cycles in both empirical studies, treading a fine line between "knowing and not-knowing" (Gioia, Corley, and Hamilton, 2013, p 21). The summary of the role of bracketing in some phenomenological framings can be seen in Table 1 . All these conceptualisations, however, say little about the implementation.

It was when we started thinking about how we would implement bracketing as a methodological tool that we started to understand it better as a theoretical construct. As argued by Eden and Ackermann (2018) in relation to one purpose of action research being the way in which theory is developed through attempting its application. The reason is that implementation raises simple problems, such as: 'How can I now forget what I have previously known about cooking?' 'I cannot stop believing that the master-apprentice relationship is important!' Bracketing does not mean stopping things from happening. We do not stop believing in something, instead, we make our belief explicit, so that we can consider how it may affect our understanding (cf Eden and Ackermann, 2018). This also means that all the terms that we use to help explain bracketing, such as suspending, refraining, holding back, etc. are not really good descriptors, as they suggest that we can stop from happening what we bracket out. However, bracketing is more about making conscious what is happening anyway, whether we like it or not. Furthermore, we can stop acting upon something we want to bracket, and that can help. For instance, we cannot remove our beliefs and values, but we can refrain from judgement, explicitly acknowledge our beliefs and values that would prompt judgement, and use them as sources of insights. With such improved comprehension, we finally ventured into intentionally implementing bracketing. Finally, we have implemented the theoretical construct of bracketing in two stages in both studies (the first through personal, the second through transpersonal reflexivity), although the order of these stages was different, and it was practiced at different phases of the research process (Figure 1). 
Table 1: Bracketing in relation to some phenomenological frameworks

\begin{tabular}{|c|c|c|}
\hline $\begin{array}{l}\text { Phenomenology } \\
\text { Main authors }\end{array}$ & Research objective & Bracketing \\
\hline $\begin{array}{l}\text { Descriptive Phenomenology } \\
\text { Giorgi }(1975,1985 a, 1997, \\
\text { 2006) }\end{array}$ & $\begin{array}{l}\text { Describe the essential } \\
\text { structure of the lived } \\
\text { experience. }\end{array}$ & $\begin{array}{l}\text { Look at the data with the } \\
\text { attitude of relative openness. }\end{array}$ \\
\hline $\begin{array}{l}\text { Heuristic Inquiry } \\
\text { Douglass and Moustakas } \\
\text { (1985) and Moustakas (1990, } \\
\text { 1994) }\end{array}$ & $\begin{array}{l}\text { Produce a description through } \\
\text { creative synthesis to explicate } \\
\text { lived experience challenging } \\
\text { extreme levels of perception.. }\end{array}$ & $\begin{array}{l}\text { Balance passion and discipline, } \\
\text { take subjectivity to extreme } \\
\text { and discuss with others } \\
\text { experiences to root out } \\
\text { meanings completely. }\end{array}$ \\
\hline $\begin{array}{l}\text { Relational Phenomenology } \\
\text { Finlay }(2008 a, 2009) \text { and Finlay } \\
\text { and Evans }(2009)\end{array}$ & $\begin{array}{l}\text { Capture individual variations } \\
\text { between co-researchers to } \\
\text { understand the experiencing } \\
\text { person. }\end{array}$ & $\begin{array}{l}\text { Open yourselves to being } \\
\text { moved by an Other; manage } \\
\text { evolving understandings in a } \\
\text { relational context. }\end{array}$ \\
\hline $\begin{array}{l}\text { Phenomenology of Perception } \\
\text { Merleau-Ponty (1945) }\end{array}$ & $\begin{array}{l}\text { Perceive the totality (Gestalt) } \\
\text { of the embodied experience. }\end{array}$ & $\begin{array}{l}\text { Acknowledge the parallel } \\
\text { existence of a priori and de } \\
\text { facto, try pushing back the } \\
\text { opacity, accepting that it is } \\
\text { impossible to eliminate it. }\end{array}$ \\
\hline $\begin{array}{l}\text { Hermeneutic Phenomenology } \\
\text { Gadamer }(1975,1989)\end{array}$ & $\begin{array}{l}\text { Understand the knower and } \\
\text { the known, as inseparable, in } \\
\text { context, each with its own } \\
\text { historicity. }\end{array}$ & $\begin{array}{l}\text { Look beyond the world and } \\
\text { scientific knowledge to access } \\
\text { the pure subjectivity while } \\
\text { accepting that the 'I' is also in } \\
\text { the Lebenswelt. }\end{array}$ \\
\hline $\begin{array}{l}\text { Reflective Lifeworld Approach } \\
\text { Dahlberg, Dahlberg, and } \\
\text { Nystrom (2008) }\end{array}$ & $\begin{array}{l}\text { Elucidate the Lebenswelt in } \\
\text { which the person's sense of } \\
\text { self-identity and embodied } \\
\text { relations affect the } \\
\text { experiencing. }\end{array}$ & $\begin{array}{l}\text { Have patience for phenomena } \\
\text { to reveal their complexities } \\
\text { rather than impose models. }\end{array}$ \\
\hline $\begin{array}{l}\text { Interpretative } \\
\text { Phenomenological Analysis } \\
\text { (IPA) } \\
\text { Smith and Osborn (2008) }\end{array}$ & $\begin{array}{l}\text { Make general claims on the } \\
\text { basis of examining } \\
\text { idiosyncratic lived experiences } \\
\text { of participants. }\end{array}$ & $\begin{array}{l}\text { Capture individual variations } \\
\text { between co-researchers in } \\
\text { making sense of the research } \\
\text { participants. }\end{array}$ \\
\hline $\begin{array}{l}\text { Critical Narrative Analysis } \\
\text { (CNA) } \\
\text { Langdridge (2007) }\end{array}$ & $\begin{array}{l}\text { Co-create stories of } \\
\text { experiencing with the } \\
\text { participants in the research } \\
\text { context. }\end{array}$ & $\begin{array}{l}\text { Disclose the learning process } \\
\text { through which the researcher } \\
\text { achieved a confidence in } \\
\text { understanding the } \\
\text { phenomenon from the } \\
\text { participants' perspective. }\end{array}$ \\
\hline
\end{tabular}




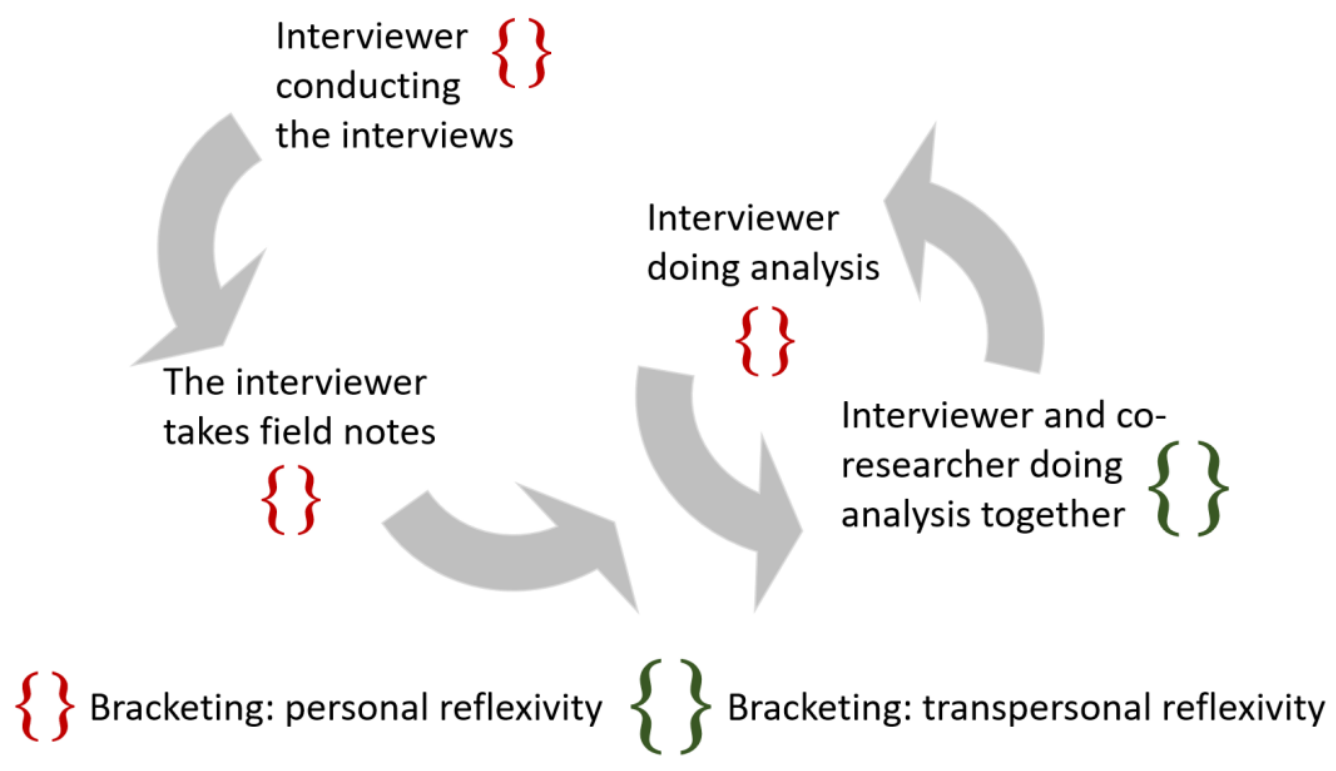

Figure 1: Instances of bracketing

The first stage of bracketing (personal reflexivity, red braces on Figure 1), primarily corresponding to epoché and to a lesser extent to the phenomenological psychological reduction, was practised by the interviewer; this stage was primarily focused on suspending judgement in order to arrive at an intuitive understanding of the interviewees' subjective accounts of their lived experiences. This stage of bracketing took place in two phases of the research process, the data collection and the analysis. The first, and with hindsight remarkably important, instance of bracketing happens during the interview. By bracketing out the pre-understandings, beliefs, and values the interviewer keeps an open mind and listens to the participant better. The second instance of bracketing is still within the data collection phase; it happens when the interviewer prepares the field notes. This immediate recollection of the interviewing experience, with all aspects of the Dasein and Lebenswelt, also gives a chance to raise awareness of bracketing missed during the interview process. Later, when the interviewer engages in the analysis, the bracketing is practiced again (third instance), trying to make sense of the rich data collected. This happened at different phases of the analysis in the two projects. In the Extraordinary Chefs study, the interviewer did the first step of the analysis on his own, and in this descriptive phase, it was very important to be faithful to the participants' accounts. In the Extraordinary Scientists study the first phase of the analysis happened between the two researchers, and the interviewer was working with the data by himself only later, when he was coding the interview and other material. However, the order of phases is the only difference; the attitude to bracketing was the same in both cases. The three instances of bracketing described so far are pursued by the interviewer alone, and they all involve personal reflexivity (cf Finlay, 2008a) rather than transpersonal reflexivity.

However, more interesting was how we implemented the second stage of bracketing, which is implemented through transpersonal reflexivity (green braces on Figure 1). This happened, in the case of both empirical projects, in the interaction between the interviewer and the coresearcher; this mainly corresponds to the phenomenological psychological reduction but 
also features elements of the transcendental phenomenological reduction. In the Extraordinary Scientists study, the first phase of analysis was in the interaction of the two researchers. The interviewer was interviewed by the co-researcher, trying to shed light on the interviewer's intuitions and, although recognised only with hindsight, also to bracket the interviewer's pre-understandings, beliefs, and values. In the Extraordinary Chefs study, the two researchers only came together in the second phase of the analysis, once the interviewer already obtained the descriptive findings. In the second phase of the analysis the researchers created the idiographic explanations based on the descriptive findings, and they have practiced the second stage of bracketing.

The purpose of the second stage of bracketing was to raise the awareness of presumptions, previous knowledge and beliefs, of which the interviewer was not aware. This has been achieved by practising transpersonal reflexivity. Reflexivity here is conceptualised as a deeper process than simple reflectivity, and beyond subject-reflection it also includes self-reflection. (see e.g. Brannick and Coghlan, 2007; Hibbert, Sillince, Diefenbach, and Cunliffe, 2014; Hibbert and Cunliffe, 2015) Furthermore, the attached 'transpersonal' attribute is rooted in Polányi's (1962a, 1966) notion of 'personal knowledge'. Transpersonal goes beyond the notion of interpersonal, as the persons involved in the process engage in 'thinking together' (Pyrko, Dörfler, and Eden, 2017) in which the personal boundaries are transcended resulting in a single thinking process in which two or more persons are involved. Such deep engagement is necessary, as the two researchers need to attain the same essences.

In the research process this meant that the co-researcher, who was not involved in the interviews and deliberately did not read them, held a mirror to the interviewer in support of the reflexive process. Going through the cycles present in both methods also meant going back and forth between the two stages of bracketing, respectively employing personal and transpersonal reflexivity, thus achieving the above mentioned 'attitude of relative openness'. The process is time-consuming and requires deep engagement between the researchers, but it is also exceptionally fruitful - at least, in our experience from the two studies on which this paper was based.

\section{CONCLUDING REMARKS}

We believe that the two main reasons for few phenomenological studies in management and organisation scholarship are (1) a lack of understanding of bracketing as a construct and (2) its highly philosophical nature. We have addressed both of these issues in this article. More precisely, we explored the notion of bracketing at a philosophical, theoretical, and methodological level, digging into the first conceptualisation of phenomenology by Husserl. Going back and forth between the philosophical, theoretical and methodological levels, in the context of the two studies, we believe that we added substantial clarity to the essence of this construct. We have shown that in an interpretivist framework bracketing can be conceptualised as raising awareness and making explicit our pre-understandings, values, beliefs, rather than getting rid of them, which would be impossible anyway. Furthermore, if 
conceptualised this way, bracketing can be a source of insight into the essential nature of experiences. The highly philosophical nature of bracketing has been acknowledged within the management and organisation scholarship, but little has been said about how to implement and practice it as a methodological tool. We have illustrated the implementation of bracketing using two underlying empirical studies, producing hands-on guidelines for researchers who want to use bracketing in their research. By linking the notion of bracketing with reflection and reflexivity, we also highlight the role of bracketing in rigorous qualitative research in the management and organisation field. In some fields, such as psychology (Finlay, 2008a; Finlay and Evans, 2009; Fischer, 2009) and health research (Ahern, 1999; LeVasseur, 2003; Gearing, 2004), bracketing has been linked with reflection and reflexivity. However, this was always personal reflection and reflexivity, the transpersonal reflexivity is an original contribution of this article. The significance of our study therefore is an increased understanding of bracketing at a conceptual as well as applied level, which will hopefully enable a larger number of phenomenological studies in the field.

The obvious limitation of our theorising presented in this article is that it is only based on two empirical studies. However, we see this limitation as an opportunity for other management and organisation scholars to develop many further implementations. Although we believe that other studies may need somewhat different implementations, we believe that the logic of our approach, the underlying principles are robust, and further idiosyncratic implementations will confirm this.

On reflection, when we engaged in bracketing for the first time(s), in the empirical studies outlined in this article, we did so being unaware of what we were doing. Once we recognized our transpersonal reflexive processes as bracketing, we started to be more mindful about it. Whenever we were interested in the lived experience, we did engage in some form of bracketing, which was always achieved through transpersonal reflexivity. This was true when we have worked together or with other co-authors, and even when it was just one of us, we invited someone to 'bracket with' (Dörfler, 2010; Stierand and Zizka, 2015; Baracskai and Dörfler, 2017; Bas, Dörfler, and Sinclair, 2019; Miralles, Stierand, and Dörfler, 2019; Pyrko, Dörfler, and Eden, 2019; Stierand et al., 2019; Dörfler and Bas, 2020b; Harrington and Dörfler, 2020; Harrington, Dörfler, and Stierand, 2020; Miralles, Stierand, Lee, and Dörfler, 2020; Rayan, Dörfler, and Lennon, 2020; Shpakova, Dörfler, and MacBryde, 2020; Spanellis, Dörfler, and MacBryde, 2020; Stierand, Heelein, and Mainemelis, 2020). Why is it always transpersonal reflexivity? Perhaps because it is so natural to happen between co-researchers: we talk, discuss what we see, challenge each other - all in an attempt to produce the best quality research we can. Importantly, even when we do not report in a publication about bracketing, we still use it, as a way of improving our research as well as increasing our confidence in our findings. The actual process of transpersonal reflexivity through which we exercised bracketing was a little different every time, but in each case it could fit within the guidelines outlined in this article. We also see a possibility for extending the concept of bracketing beyond its natural habitat, phenomenology. How being judgemental or using our preunderstandings can pollute our research, is particularly easy in the context of 
phenomenology, as the focus is on the lived experience. However, the same things can pollute any kind of research, regardless of the focus or philosophy stance. Perhaps, it is worth thinking about a more ubiquitous conceptualisation of bracketing, that can apply in any sort of qualitative (and we also believe quantitative) research - we plan to engage in such thinking, but it is beyond the scope of this article. 


\section{REFERENCES}

Ahern, K.J. (1999), "Ten Tips for Reflexive Bracketing". Qualitative Health Research, Vol. 9 No. 3, pp. 407-411. https://doi.org/10.1177/104973239900900309

Baracskai, Z., and Dörfler, V. (2017), "An Essay Concerning Human Decisions". Transdisciplinary Journal of Engineering \& Science, Vol. 8, pp. 71-82. https://doi.org/10.22545/2017/00088

Bas, A., Dörfler, V., and Sinclair, M. (2019), "Intuiting process as sensing plus sensemaking", paper presented at the AoM 2019: 79th Annual Meeting of the Academy of Management, 9-13 August 2019, Boston, MA. https://doi.org/10.5465/AMBPP.2019.12061symposium

Bondas, T., and Hall, E.O.C. (2007), "Challenges in Approaching Metasynthesis Research". Qualitative Health Research, Vol. 17 No. 1, pp. 113-121. https://doi.org/10.1177/1049732306295879

Brannick, T., and Coghlan, D. (2007), "In Defense of Being "Native": The Case for Insider Academic Research". Organizational Research Methods, Vol. 10 No. 1, pp. 59-74. https://doi.org/10.1177/1094428106289253

Brentano, F. (1973/2014), Psychology from An Empirical Standpoint, Routledge, New York, NY.

Cassell, C., and Lee, B. (2017), "Understanding Translation Work: The evolving interpretation of a trade union idea". Organization Studies, Vol. 38 No. 8, pp. 1085-1106. https://doi.org/10.1177/0170840616670435

Chalmers, D.J. (2003), "The Content and Epistemology of Phenomenal Belief", in Smith, Q. \& Jokic, A. (Eds.), Consciousness: New Philosophical Perspectives Oxford.

Chia, R.C.H. (1995), "From Modern to Postmodern Organizational Analysis". Organization Studies, Vol. 16 No. 4, pp. 579-604. https://doi.org/10.1177/017084069501600406

Csíkszentmihályi, M. (1997), Creativity: Flow and the Psychology of Discovery and Invention, HarperCollins, New York, NY.

Dahlberg, K., Dahlberg, H., and Nystrom, M. (Eds.). (2008). Reflective lifeworld research ( ${ }^{\text {nd }}$ ed.). Lund, Sweden: Studentlitteratur.

Dörfler, V. (2010), "Learning Capability: The Effect of Existing Knowledge on Learning". Knowledge Management Research \& Practice, Vol. 8 No. 4, pp. 369-379. https://doi.org/10.1057/kmrp.2010.15

Dörfler, V., and Ackermann, F. (2012), "Understanding Intuition: The Case for Two Forms of Intuition". Management Learning, Vol. 43 No. 5, pp. 545-564. https://doi.org/10.1177/1350507611434686

Dörfler, V., and Bas, A. (2020a), "Intuition: scientific, non-scientific or unscientific?", in Sinclair, M. (Ed.), Handbook of Intuition Research as Practice, Edward Elgar, Cheltenham, UK, pp. 293305. https://doi.org/10.4337/9781788979757.00033

Dörfler, V., and Bas, A. (2020b), "Tools for Exploring the Unknowable: Intuition vs. Artificial Intelligence", paper presented at the AoM 2020: 80th Annual Meeting of the Academy of Management, 7-11 August 2020, Vancouver, BC, Canada.

Dörfler, V., and Eden, C. (2014), "Research on Intuition using Intuition", in Sinclair, M. (Ed.), Handbook of Research Methods on Intuition, Edward Elgar Publishing, Cheltenham, UK, pp. 264-276. https://doi.org/10.4337/9781782545996.00031

Dörfler, V., and Eden, C. (2017), "Becoming a Nobel Laureate: Patterns of a Journey to the Highest Level of Expertise", paper presented at the AoM 2017: $77^{\text {th }}$ Annual Meeting of the Academy 
of Management, 4-8 August 2017, Atlanta, GA.

https://doi.org/10.5465/AMBPP.2017.12982abstract

Dörfler, V., and Stierand, M. (2018), "Understanding Indwelling through Studying Intuitions of Nobel Laureates and Top Chefs", paper presented at the AoM 2018: 78th Annual Meeting of the Academy of Management, 10-14 August 2018, Chicago, IL.

Dörfler, V., and Stierand, M. (2019), "Extraordinary: Reflections on Sample Representativeness", in Lebuda, I. \& Glăveanu, V.P. (Eds.), The Palgrave Handbook of Social Creativity Research, Palgrave Macmillan, Cham, Switzerland, pp. 569-584. https://doi.org/10.1007/978-3-31995498-1 36

Douglass, B.G., and Moustakas, C. (1985), "Heuristic inquiry: the internal search to know". Journal of Humanistic Psychology, Vol. 25 No. 3, pp. 39-55. https://doi.org/10.1177/0022167885253004

Eden, C., and Ackermann, F. (2018), "Theory into Practice, Practice to Theory: Action Research in Method Development". European Journal of Operational Research, Vol. 271 No. 3, pp. 11451155. https://doi.org/10.1016/i.ejor.2018.05.061

Eliasmith, C., and Mandik, P. (2006). Dictionary of Philosophy of Mind - qualia. Dictionary of Philosophy of Mind. Retrieved 18/10/2009, from http://philosophy.uwaterloo.ca/MindDict/qualia.html

Feuls, M., Stierand, M., Dörfler, V., Boje, D., and Haley, U. (2019, 8-10 September). Exploring Practices of Managing Creativity: A Qualitative Meta-Analysis of Narratives from Haute Cuisine. Paper presented at the 20th International CINet Conference, Odense, Denmark.

Finlay, L. (2008a), "A Dance Between the Reduction and Reflexivity: Explicating the "Phenomenological Psychological Attitude"'. Journal of Phenomenological Psychology, Vol. 39 No. 1, pp. 1-32. https://doi.org/10.1163/156916208X311601

Finlay, L. (2008b). Introducing Phenomenological Research. Retrieved from http://www.lindafinlay.co.uk/phenomenology.htm

Finlay, L. (2009), "Debating Phenomenological Research Methods". Phenomenology \& Practice, Vol. 3 No. 1, pp. 6-25.

Finlay, L., and Evans, K. (2009), Relational centred qualitative research for psychotherapists and counsellors: exploring meanings and experience, Wiley-Blackwell, Oxford, UK.

Fischer, C.T. (2009), "Bracketing in qualitative research: Conceptual and practical matters". Psychotherapy Research, Vol. 19 No. 4-5, pp. 583-590. https://doi.org/10.1080/10503300902798375

Fontana, A., and Frey, J.H. (1994), "Interviewing: The Art of Science", in Denzin, N.K. \& Lincoln, Y.S. (Eds.), The SAGE Handbook of Qualitative Research, SAGE Publications, Thousand Oaks, CA, pp. 361-376.

Gadamer, H.-G. (1975), "Hermeneutics and Social Science". Cultural Hermeneutics, Vol. 2 No. 4, pp. 307-316. https://doi.org/10.1177/019145377500200402

Gadamer, H.-G. (1989/2006), Truth and Method ( $2^{\text {nd }}$ ed.), Continuum, London, UK.

Gardner, H. (1993), Creating Minds: An Anatomy of Creativity Seen through the Lives of Freud, Einstein, Picasso, Stravinsky, Eliot, Graham, and Gandhi, Basic Books, New York, NY.

Gardner, H. (1995), Leading Minds: An Anatomy of Leadership, Harper Collins Publishers, London, UK. 
Gardner, H. (1997), Extraordinary Minds: Portraits of Exceptional Individuals and an Examination of Our Extraordinariness, Phoenix, London, UK.

Gearing, R.E. (2004), "Bracketing in Research: A Typology". Qualitative Health Research, Vol. 14 No. 10, pp. 1429-1452. https://doi.org/10.1177/1049732304270394

Gioia, D.A., Corley, K.G., and Hamilton, A.L. (2013), "Seeking Qualitative Rigor in Inductive Research: Notes on the Gioia Methodology". Organizational Research Methods, Vol. 16 No. 1, pp. 1531. https://doi.org/10.1177/1094428112452151

Giorgi, A. (1975), "An Application of Phenomenological Method in Psychology", in Giorgi, A., Fischer, C. \& Murray, E. (Eds.), Duquesne Studies in Phenomenological Psychology: Volume II, Duquesne University Press, Pittsburgh, PA, pp. 82-103.

Giorgi, A. (1985a), Phenomenology and Psychological Research, Duquesne University Press, Pittsburgh, PA.

Giorgi, A. (1985b), "Sketch of a psychological phenomenological method", in Giorgi, A. (Ed.), Phenomenology and psychological research, Duquesne University Press, Pittsburgh, PA, pp. 8-22.

Giorgi, A. (1994), "A Phenomenological Perspective on Certain Qualitative Research Methods". Journal of Phenomenological Psychology, Vol. 25 No. 2, pp. 190-220. https://doi.org/10.1163/156916294X00034

Giorgi, A. (1997), "The theory, practice, and evaluation of the phenomenological method as a qualitative research procedure". Journal of Phenomenological Psychology, Vol. 28 No. 2, pp. 235-260.

Giorgi, A. (2006), "Difficulties Encountered in the Application of the Phenomenological Method in the Social Ssciences". Análise Psicológica, Vol. 24 No. 3, pp. 353-361. https://doi.org/10.1080/20797222.2008.11433956

Harrington, S., and Dörfler, V. (2020), "Twitter Sentiment Analysis \& Machine Learning in Threshold Concept Identification", paper presented at the BAM 2020: : $34^{\text {th }}$ Annual Conference of the British Academy of Management, 2-4 September 2020, Manchester, UK.

Harrington, S., Dörfler, V., and Stierand, M. (2020), "Towards a Participatory Autoethnography to Explore Threshold Moments in Autistic Adults", paper presented at the EURAM 2020: $20^{\text {th }}$ Annual Conference of the European Academy of Management, 4-6 December 2020, Dublin, Ireland.

Heidegger, M. (1923/1999), Ontology: The Hermeneutics of Facticity, Indiana University Press, Bloomington, IN.

Heidegger, M. (1975/1988), The Basic Problems of Phenomenology, Indiana University Press, Bloomington, IN.

Hibbert, P., and Cunliffe, A.L. (2015), "Responsible Management: Engaging Moral Reflexive Practice Through Threshold Concepts". Journal of Business Ethics, Vol. 127 No. 1, pp. 177-188. https://doi.org/10.1007/s10551-013-1993-7

Hibbert, P., Sillince, J., Diefenbach, T., and Cunliffe, A.L. (2014), "Relationally Reflexive Practice: A Generative Approach to Theory Development in Qualitative Research". Organizational Research Methods, Vol. 17 No. 3, pp. 278-298. https://doi.org/10.1177/1094428114524829

Husserl, E. (1913a/1983), Ideas Pertaining to a Pure Phenomenology and to a Phenomenological Philosophy: First Book: General Introduction to a Pure Phenomenology, Kluwer Academic Publishers, Dordrecht, Netherlands. 
Husserl, E. (1913b/1990), Ideas Pertaining to a Pure Phenomenology and to a Phenomenological PhilosophySecond Book: Studies in the Phenomenology of Constitution, Kluwer Academic Publishers, Dordrecht, Netherlands.

Husserl, E. (1931/1999), Cartesian Meditations (Cairns, D., Trans.), Kluwer, Dordrecht.

Husserl, E. (1936/1970), Crisis of European Sciences and Transcendental Phenomenology, Northwestern University Press, Evanston, II.

Husserl, E. (1965), Phenomenology and the Crisis of Philosophy. Philosophy as Rigorous Science and Philosophy and the Crisis of European Man. Translated with Notes and an Introduction by Quentin Lauer, Harper Torchbooks, New York, NY.

Husserl, E. (2006), The Basic Problems of Phenomenology: From the Lectures, Winter Semester, 19101911 (Farin, I. \& Hart, J.G., Trans.), Springer, Dordrecht, Netherlands.

Jackson, F. (1982), "Epiphenomenal Qualia". The Philosophical Quarterly, Vol. 32 No. 127, pp. 127136. https://doi.org/10.2307/2960077

Langdridge, D. (2007), Phenomenological Psychology: Theory, Research and Method, Pearson Education, Harlow, UK.

LeVasseur, J.J. (2003), "The Problem of Bracketing in Phenomenology". Qualitative Health Research, Vol. 13 No. 3, pp. 408-420. https://doi.org/10.1177/1049732302250337

Lewis, C.I. (1929), Mind and the World Order: Outline of a Theory of Knowledge, Charles Scribner's Sons, New York, NY.

Maslow, A.H. (1968), Toward a Psychology of Being (2 ${ }^{\text {nd }}$ ed.), Van Nostrand Reinhold, New York, NY.

Maslow, A.H. (1970/1994), Religions, Values, and Peak-Experiences, Penguin, New York, NY.

Merleau-Ponty, M. (1945/2005), Phenomenology of Perception, Routledge \& Kegan Paul, London, UK.

Miralles, M., Stierand, M., and Dörfler, V. (2019), "Frozen in Time: Unfolding Experiences in Archival Process Data", paper presented at the BAM 2019: $33^{\text {rd }}$ Annual Conference of the British Academy of Management, 3-5 September 2019, Birmingham, UK.

Miralles, M., Stierand, M., Lee, B., and Dörfler, V. (2020), "Methodological and Emotional Challenges of Studying Traumatic Experiences", paper presented at the BAM 2020: $34^{\text {th }}$ Annual Conference of the British Academy of Management, 2-4 September 2020, Manchester, UK.

Moran, D. (2000), Introduction to Phenomenology, Routledge, London, UK.

Moustakas, C. (1990), Heuristic Research: Design, Methodology, and Applications, Sage, Thousand Oaks, CA.

Moustakas, C. (1994), Phenomenological Research Methods, Sage, Thousand Oaks, CA.

Nakamura, J., Shernoff, D.J., and Hooker, C.H. (2009), Good Mentoring: Fostering Excellent Practice in Higher Education, Jossey-Bass, San Francisco, CA.

Park, Y.A., and Gretzel, U. (2007), "Success Factors for Destination Marketing Web Sites: A Qualitative Meta-Analysis". Journal of Travel Research, Vol. 46 No. 1, pp. 46-63. https://doi.org/10.1177/0047287507302381

Polányi, M. (1962a/2002), Personal Knowledge: Towards a Post-Critical Philosophy, Routledge, London, UK.

Polányi, M. (1962b), "Tacit Knowing: Its Bearing on Some Problems of Philosophy". Reviews of Modern Physics, Vol. 34 No. 4, pp. 601-616. 
Polányi, M. (1966/1983), The Tacit Dimension, Peter Smith, Gloucester, MA.

Polányi, M. (1969), "The Creative Imagination". Psychological Issues, Vol. 6 No. 2, pp. 53-91.

Pyrko, I., Dörfler, V., and Eden, C. (2017), "Thinking Together: What Makes Communities of Practice Work?". Human Relations, Vol. 70 No. 4, pp. 389-409.

https://doi.org/10.1177/0018726716661040

Pyrko, I., Dörfler, V., and Eden, C. (2019), "Communities of practice in landscapes of practice". Management Learning, Vol. 50 No. 4, pp. 482-499. https://doi.org/10.1177/1350507619860854

Rayan, S., Dörfler, V., and Lennon, M. (2020), "Struggles, Strengths, And Strategies: An Online Ethnographic Study Of Self-Management Of Type 1 Diabetes", paper presented at the BAM 2020: $34^{\text {th }}$ Annual Conference of the British Academy of Management, 2-4 September 2020, Manchester, UK.

Sadler-Smith, E. (2008), Inside Intuition, Routledge, London, UK.

Sandelowski, M., and Barroso, J. (2007), Handbook for Synthesizing Qualitative Research, Springer Publishing Company, New York, NY.

Shpakova, A., Dörfler, V., and MacBryde, J. (2020), "Gamifying the process of innovating". Innovation: Organization \& Management, Vol. 22 No. 4. https://doi.org/10.1080/14479338.2019.1642763

Smith, J.A., and Osborn, M. (2008), "Interpretative phenomenological analysis", in Smith, J.A. (Ed.), Qualitative psychology: a practical guide to research methods ( $2^{\text {nd }}$ ed., Sage, London, UK, pp. 53-80.

Spanellis, A., Dörfler, V., and MacBryde, J. (2020), "Investigating the Potential for Using Gamification to Empower Knowledge Workers". Expert Systems with Applications, Vol. 160. https://doi.org/10.1016/j.eswa.2020.113694

Stierand, M. (2015), "Developing Creativity in Practice: Explorations with World-Renowned Chefs". Management Learning, Vol. 46 No. 5, pp. 598-617. https://doi.org/10.1177/1350507614560302

Stierand, M., Boje, D.M., Glăveanu, V.P., Dörfler, V., Haley, U., and Feuls, M. (2019), "Paradoxes of Creativity: Examining the Creative Process Through an Antenarrative Lens". Journal of Creative Behavior, Vol. 53 No. 2, pp. 165-170. https://doi.org/10.1002/jocb.224

Stierand, M., and Dörfler, V. (2012), "Reflecting on a Phenomenological Study of Creativity and Innovation in Haute Cuisine". International Journal of Contemporary Hospitality Management, Vol. 24 No. 6, pp. 946-957. https://doi.org/10.1108/09596111211247254

Stierand, M., and Dörfler, V. (2014), "Researching Intuition in Personal Creativity", in Sinclair, M. (Ed.), Handbook of Research Methods on Intuition, Edward Elgar Publishing, Cheltenham, UK, pp. 249-263. https://doi.org/10.4337/9781782545996.00030

Stierand, M., and Dörfler, V. (2016), "The Role of Intuition in the Creative Process of Expert Chefs". Journal of Creative Behavior, Vol. 50 No. 3, pp. 178-185. https://doi.org/10.1002/jocb.100

Stierand, M., Dörfler, V., and MacBryde, J. (2014), "Creativity and Innovation in Haute Cuisine: Towards a Systemic Model". Creativity and Innovation Management, Vol. 23 No. 1, pp. 1528. https://doi.org/10.1111/caim.12050

Stierand, M., Heelein, J., and Mainemelis, C. (2020), "A Designer on Designing: A Conversation with Johannes Torpe". Journal of Management Inquiry, Vol. 29 No. 3, pp. 350-359.

https://doi.org/10.1177/1056492619882090 
Stierand, M., and Zizka, L. (2015), "Reflecting on Hospitality Management Education through a Practice Lens". Quality Assurance in Education, Vol. 23 No. 4, pp. 353-363. https://doi.org/10.1108/QAE-04-2015-0013

Varela, F.J., and Shear, J. (1999a), "First-person Methodologies: What, Why, How?". Journal of Consciousness Studies, Vol. 6 No. 2-3, pp. 1-14.

Varela, F.J., and Shear, J. (Eds.). (1999b). The View from Within: First-Person Approaches to the Study of Consciousness. Bowling Green, $\mathrm{OH}$ : Imprint Academic.

Whitehead, A.N. (1926/1967), Science and the Modern World, Free Press, New York, NY.

Wittgenstein, L.J.J. (1979), On Certainty (Paul, D. \& Anscombe, G.E.M., Trans.), Blackwell, Oxford, UK.

Woolgar, S. (1988), Science, the very idea, Ellis Horwood, Sussex, UK.

Zaner, R.M. (1975), "On the Sense of Method in Phenomenology", in Pivčević, E. (Ed.), Phenomenology and Philosophical Understanding, Cambridge University Press, London, UK, pp. 122-138. 